\title{
OCHRONA PRAW UBOGICH W KANONICZNYM PROCESIE O NIEWAŻNOŚĆ MAŁŻEŃSTWA
}

Treść: Wstęp. - 1. Godność człowieka podstawą jego praw. - 2. Problem ubóstwa. -2.1. Ubodzy w nauczaniu Kościoła. - 2.2. Problem współczesnego ubóstwa w Polsce. - 3. Prawa ubogich w procesie de nullitatae. -4 . Ochrona praw ubogich. -4 .1. Koszta sądowe. - 4.1.1. Kryteria przyznawania pomocy. - 4.1.2. Decyzja. - 4.1.3. Odwołanie się od decyzji. - 4.1.4. Skutki. - 4.2. Pomoc prawna. Zakończenie.

\section{Wstęp}

Bezsprzecznie ostatnie lata pokazały ogromny rozwój myśli prawnej wokół praw przysługujących człowiekowi. Druga połowa dwudziestego wieku stała się okresem wzmożonej walki o prawa człowieka. Skutkiem tego są obowiązujące w wielu państwach liczne akty normatywne o charakterze międzynarodowym. Przestrzeganie praw człowieka stało się dziś wizytówką państw, które chcą się „liczyć” na arenie międzynarodowej. Państwa prześcigają się w takim prawodawstwie, które w możliwie najszerszy sposób będą akcentowały prawa człowieka. To dobry znak. Jednocześnie niestety coraz częściej mamy do czynienia z brakiem zrozumienia czym w ogóle jest prawo, ale paradoksalnie zapominamy także o człowieku.

Człowiek i prawo są nierozłączne. Ubi societas ibi ius. Bez względu na porządek prawny, świecki czy kanoniczny, prawo ma pomagać człowiekowi. W to stwierdzenie wpisuje się temat niniejszego przedłożenia. Na przykładzie kanonicznego procesu o nieważność małżeństwa zostanie ukazana ochrona praw osób ubogich. 


\section{Godność człowieka podstawą jego praw}

Jednym z podstawowych terminów stanowiących źródło praw człowieka jest godność człowieka ${ }^{1}$. Nie jest ona wymysłem teoretyków i filozofów prawa, ale jest ściśle związana z początkiem stworzenia. Bóg stwarzając świat, na sam koniec stworzył człowieka. Jest on dzieckiem Bożym, stworzonym na wzór i podobieństwo samego Boga. Człowiek to istota, która zajmuje naczelne miejsce w hierarchii świata bioetycznego. Jednocześnie człowiek wykracza poza świat ożywiony ze względu na właściwości duchowe. Człowieka przy stworzeniu uzyskał od Boga godność. Prawdą jest, iż nadwyrężył ją przez grzech, ale została ona ponownie dowartościowana przez ofiarę Chrystusa. Człowiek zostaje stworzony na nowo ${ }^{2}$.

Natura człowieka skupia w sobie zarówno cielesność jak i duchowość. Człowiek jest podzielony w samym sobie, ale pomimo tego winien jest z szacunkiem odnosić się do swojego ciała. To właśnie godność człowieka, jak naucza Sobór Watykański II, wymaga aby chwalił

${ }^{1}$ Zob. H. KocH, Godność człowieka - niezbywalnym prawem i fundamentem ładu społecznego, Legnickie Studia Teologiczno-Historyczne, Rok VI, 2007, nr 1(10), s. 90-104; F. J. MAZUREK, Godność osoby ludzkiej podstawa praw człowieka, Lublin 2001; M. OssowsKa, Normy moralne w obronie godności człowieka, Etyka 5(1969), s. 7-27; H. PiLus, Godność człowieka jako osoby, Warszawa 1997; B. STAŃKowski, Godność osoby - implikacje na polu wychowawczym, Seminare 25(2008), s. 341-352. Natomiast słowo godność - łacińskie dignitas, wg Encyklopedii Katolickiej, oznacza szczególną wartość człowieka jako osoby, pozostającej w relacjach interpersonalnych, ostatecznie do osoby Boga, uzasadniających i usensowniających życie osobowe. Oznacza także pozytywnie wartościującą relację do własnej osoby i grupy, np. zawodowej, klasowej, narodowej, z którym jednostka się identyfikuje. Konstytuującym komponentem tego ustosunkowania się jest samoocena polegająca na przeżywaniu swojej wartości i pozytywnego obrazu siebie, która motywuje do moralnie wartościowych zachowań, uodparnia na wszelkie formy manipulacji, zniewalania, wpływa na radzenie sobie w sytuacjach trudnych oraz zakłada poczucie wewnętrznej wolności, autodeterminacji (podmiotowości) i odpowiedzialności. Por. Z. CHLEwiŃsKi, Z. ZALESKI, Godność, w: Encyklopedia katolicka. t. 5, pod red. L. Bieńkowskiego [i in.]. Lublin 1989, s. 1231.

2 Por. Jan Pawet II, Encyklika Redemptor hominis, nr 8, AAS 71(1979), n. 4, s. $270-272$. 
on Boga w swoim ciele ${ }^{3}$. W głębi swojego sumienia człowiek odkrywa podstawowe prawo: czyń dobrze a zła unikaj. To prawo wpisał w jego serce sam Bóg. Posłuszeństwo temu właśnie prawu stanowi o godności człowieka ${ }^{4}$. Osobista godność jest najcenniejszym dobrem człowieka, który dzięki niej przewyższa swoją wartością cały świat materialny ${ }^{5}$. Ona wyróżnia człowieka na tle innych istot. Jan XXIII nauczał, iż każdy człowiek jest osobą. To oznacza, iż obdarzony rozumem i wolną wolą posiada prawa i obowiązki wypływające bezpośrednio i równocześnie z jego własnej natury ${ }^{6}$. Są one powszechne i nienaruszalne i dlatego też nikt nie może się ich wyzbyć ${ }^{7}$. T. Styczeń twierdzi, że godność jest właściwością osoby ludzkiej, która utożsamia się z osobą i odsłania w doświadczeniu moralnym oraz jawi się w powinnościowych odniesieniach w stosunku do siebie i innych osób ${ }^{8}$.

W płaszczyźnie horyzontalnej godność osoby ludzkiej stanowi o równości wszystkich ludzi. Bóg, Stwórca człowieka, powołuje go do istnienia dając mu różne talenty, ale każdego wyposaża w tą samą

${ }^{3}$ Por. SoBór WatYKAŃSKI II, Konstytucja duszpasterska o Kościele $w$ świecie współczesnym Gaudium et spes, nr 14, w: Sobór Watykański II, Konstytucje, Dekrety, Deklaracje, tł. polskie, Poznań 2002, s. 535.

4 Por. Sobór Watykański II, Gaudium et spes, nr 16, s. 536.

5 Por. Jan Pawet II, Adhortacja Apostolska Christifideles laici, nr 37, w: Adhortacje Apostolskie Ojca Świętego Jana Pawła II, Kraków 1997, s. 416.

${ }^{6}$ Por. JAN XXIII, Pacem in terries, nr 9, AAS 55(1963), n. 5, s. 259.

7 Por. PIus XII, Orędzie radiowe wygłoszone $w$ wigilię Bożego Narodzenia 1942 r., AAS 35(1943), s. 9-24. Warto także w tym miejscu przywołać świecką doktrynę prawną. M. Jabłoński omawiając przyrodzoność praw człowieka stwierdza, iż ,niezależnie od tego, co sobą człowiek reprezentuje, według jakiego modelu wartości żyje, nikt, to znaczy ani państwo, jego organy, ani inne jednostki, nawet sam człowiek, uprawnień tych pozbawić się nie może. Są to więc wartości przypisane z samego faktu bycia człowiekiem, czyli bytem wyjątkowym, odmiennym ze względu na swą świadomość od innych żywych stworzeń, który nie może być instrumentem władzy państwowej (aspekt ontologiczny), który posiada przyrodzoną zdolność do podejmowania wspólnych decyzji (aspekt etyczny), jest stworzony na obraz i podobieństwo Boże (aspekt teologiczny) i dla którego jednym z podstawowych determinantów działania jest rozum i wolność (aspekt metafizyczny)". Por. M. JABŁoński, Przyrodzoność praw człowieka, w: Leksykon obywatela, pod red. S. Serafina, B. Szmulika, Warszawa 2008, s. 216.

8 Por. T. Styczeń, $W$ drodze do etyki, Lublin 1984, s. 269-272. 
niezbywalną godność. Ze względu na nią, wszyscy tworzymy jedną wspólnotę. W dobrej wspólnocie nie ma lepszych i gorszych, lecz wszyscy pod przewodnictwem Pasterza dążą do określonego celu. Równość jak podkreśla Jan Paweł II zakłada brak jakiejkolwiek dyskryminacji. To ona staje się środkiem rozbijającym wspólnotę. Dyskryminacja w jakiejkolwiek dziedzinie życia, czy to społecznej, obywatelskiej, kulturowej, rasowej czy wreszcie ekonomicznej jest niedopuszczalną niesprawiedliwością. Przynosi ona hańbę godności osoby ludzkiej: nie tylko godności tego, kto pada ofiarą niesprawiedliwości, ale znacznie bardziej godności tego, kto niesprawiedliwości się dopuszcza9 .

Jednakże jak pokazuje nam historia, wiek XX był najtragiczniejszym okresem eksterminacji człowieka, a z drugiej strony był wiekiem uświadomienia sobie raz jeszcze i na nowo, kim jest człowiek. Powrót do źródeł człowieczeństwa okazał się nader inspirującym dla współczesnego prawoznawstwa. Wielość paktów, umów, rezolucji zarówno międzypaństwowych, kontynentalnych jak i o charakterze międzynarodowym podkreśla tylko wyjątkowy charakter - godność człowieka. Powszechna Deklaracja Praw Człowieka z 10 grudnia 1948 r. zarówno w preambule jak i w 1 artykule przedkłada odniesienie praw człowieka do jego godności. Czytamy tam, iż godność człowieka jest podstawą wolności, sprawiedliwości i pokoju świata. Ze względu na godność człowieka wszyscy jesteśmy wolni i równi wobec prawa ${ }^{10}$. To właśnie dlatego prawa człowieka są pierwotne. Nie wynikają one bowiem ani z woli państwa i jego prawodawcy, ale z faktu bycia człowiekiem, który jest podmiotem prawa, ale z jego godności.

Godność osoby ludzkiej podkreśla z całą wyrazistością, iż człowieka nie można sprowadzić do tego co mogło by go zniszczyć i unicestwić w anonimowości kolektywu, instytucji, struktury czy systemu. Osoba w swojej wyjątkowej indywidualności nie jest numerem, ogniwem łańcucha ani trybem jakiegokolwiek systemu ${ }^{11}$. Jak zauważa

9 Por. Jan PaweŁ II, Christifideles laici, nr. 37.

${ }^{10}$ Powszechna Deklaracja Praw Człowieka, 10 grudnia 1948, w: Kościelne Prawo Publiczne. Wybór źródeł, pod red. M. Sitarza, Lublin 2012, s. 590-596.

${ }^{11}$ Por. Jan Pawee II, Christifideles laici, nr 37. 
T. Gałkowski porządek istnienia nie jest obojętny dla ludzkiej godności. Istnieje pomiędzy nimi zależność, którą Kościół nade wszystko podkreśla. Ów porządek wyraża się w lex naturalis. Natomiast kwestie dotyczące osoby i jej godności weryfikują się w stosunkach pomiędzy ludźmi oraz ludźmi a organizacją społeczną ${ }^{12}$.

\section{Problem ubóstwa}

\subsection{Ubodzy w nauczaniu Kościoła}

Współczesne społeczeństwo, dalekie od wspólnot pierwotnych, jest w sobie bardzo różnorodne i to pod wieloma aspektami. Próbując wyróżnić różne grupy dzielimy je ze względu na cechy, zakres, rodzaj, etc. Ze względu na stan majątkowy wśród społeczeństwa wyróżnia się grupę, którą nazywa się ubogimi. Są to ludzie, którzy notorycznie żyją poniżej pewnego minimum bytowego. Oczywiście granica tego minimum jest różna zależna przede wszystkim od miejsca na świecie. Zależy ona od poziomu materialnego ogółu społeczeństwa zamieszkującego dany obszar. To co bezwzględnie wyróżnia te osoby to życie w skrajnych warunkach mieszkaniowych, brak pracy, a co za tym idzie brak środków finansowych potrzebnych do godnej egzystencji. Sytuacją skrajną jest brak domu, życie na ulicy, żebranie o jedzenie lub środki na zakup jedzenia. W Europie do ubogich zalicza się lokatorów mieszkań socjalnych, żyjących z zasiłków.

Chrystus utożsamiał się z ubogimi oraz specjalnie się o nich troszczył. To dlatego Kościół od zawsze był blisko ubogich ${ }^{13}$. Kierowała nim wyłącznie troska i odpowiedzialność za człowieka, powierzonego mu przez samego Chrystusa. Kościół nie może więc opuścić człowie-

${ }^{12}$ Por. T. GaŁkowski, Prawo-obowiazek. Pierwszeństwo i wspólzależność w porządkach prawnych: kanonicznym i społeczności świeckiej, Warszawa 2007, s. 302-303.

${ }^{13}$ Kościół dostrzega problem ubóstwa w różnych jego wymiarach, co wpływa na różne pojęcie ludzi ubogich. Jan Paweł II wyróżnia trzy sfery, które mogą wpływać na braki konkretnego człowieka, czyniąc go ubogim. Są to: sfera ekonomiczna, społeczno-polityczna, kulturowa. Por. Jan PAweŁ II, Sollicitudo rei socialis, n. 26, AAS 80(1988), n. 5, s. 513-586. 
$\mathrm{ka}^{14}$. Nie czyni tego, czego przykładem są liczne wypowiedzi papieży drugiej połowy XX wieku. Zwracają oni uwagę przede wszystkim na rozległość problemu ubóstwa w świecie. Wyrażają troskę o los każdego człowieka pozostającego w takiej sytuacji, niejednokrotnie bez nadziei na lepszą przyszłość. Kościół nie tylko dostrzega problem, ale przedkłada jego źródła i daje wskazówki jak z nim walczyć ${ }^{15}$. Jan Paweł II w encyklice Sollicitudo rei socialis pytał: „,czy tak smutna dzisiejsza rzeczywistość nie jest, przynajmniej częściowo, wynikiem zbyt ograniczonej, to znaczy przede wszystkim ekonomicznej koncepcji rozwoju"16. To głód i brak środków do życia są dzisiaj największą plagą pustoszącą społeczeństwa. Kościół apelował wielokrotnie o pracę i godne wynagrodzenie, jako czynniki ograniczające sfery ubóstwa materialnego ${ }^{17}$.

\subsection{Problem współczesnego ubóstwa w Polce}

Sytuacja materialna w Polsce według różnego rodzaju statystyk jak się okazuje jest całkiem dobra. Rzeczywistość jest jednak zupełnie inna. Ciągle obserwujemy wiele osób cierpiących ubóstwo w naszym kraju. Przyczyn takiego stanu rzeczy jest wiele: zmiany ustrojowe po 1989 r., brak pracy, dyskryminacja na rynku pracy, patologie społeczne, etc. Przyczyniają się one bezsprzecznie do powstawania enklaw biedy, gdzie ludzi nie stać na jedzenie, na opłaty związane z mieszkaniem, na leczenie. Częstokroć ludzie dokonują tragicznych wyborów: kupić jedzenie albo wykupić lekarstwa. Najlepiej tę sytuację opisują badania opinii publicznej prowadzone na bazie ankiet. Wyniki są zastraszające. Rośnie bowiem liczba ludzi, którym wystarcza akurat pieniędzy na przeżycie. Coraz więcej osób nie opłaca regularnie swoich świadczeń ${ }^{18}$.

${ }^{14}$ Por. Jan PaweŁ II, Encyklika Centesimus annus, nr 53, AAS 83(1991), n. 10, s. 859-860.

${ }^{15}$ Por. Jan Pawet II, Centesimus annus, dz.cyt., s. 793-867; Jan PaweŁ II, Sollicitudo rei socialis, dz.cyt.; JAN PAWE⿺ II, Encyklika Laborem exercens, AAS 73(1981), n. 9.

${ }^{16}$ Por. Jan PAwEe II, Sollicitudo rei socialis, nr 16.

${ }^{17}$ Zob. LeON XIII, Encyklika Rerum novarum, JAN Pawet II, Laborem exercens, dz.cyt, s. 577-647; Sobór WaTYKAŃSKi II, Gaudium et spes, nr 63-72.

${ }^{18}$ Badania przeprowadzone w 2000 r. pokazały, iż sytuacja materialna większości 
Niejednokrotnie właśnie $\mathrm{w}$ takiej sytuacji życiowej przychodzi osobom występować na drogę procesową z prośbą o stwierdzenie nieważności ich małżeństwa. Zapewne jest to dla nich trudna sytuacja, również pod kątem finansowym. Jakkolwiek nieprawdą są przedkładane przez różne osoby informacje na temat kosztów związanych z „,rozwodem kościelnym" (jak to ujmują), to prawdą już jest, że trybunały kościelne ponoszą koszty związane z prowadzeniem takiego procesu. Koszta sądowe są różne i zgodnie z kan. 1649 KPK, biskup powinien ustanowić stosowne przepisy, które pozwolą na ich określenie. Poza przypadkami rzeczywistego ubóstwa czy bardzo trudnej sytuacji materialnej osób, zdarzają się niestety przypadki nieprawdziwego przed-

polskich rodzin jest przeciętna. Ponad połowa badanych (54\%) zadeklarowała, iż wystarcza im jedynie na bieżące wydatki. W gorszej sytuacji znajduje się około jedna czwarta obywateli (28\%). Osoby te czasami lub od dłuższego czasu nie są w stanie opłacać podstawowych świadczeń. Najmniej liczną grupę wśród Polaków (17\%) stanowią rodziny dobrze sytuowane tzn. takie, które czasami lub często stać jest na ekstra wydatki. Por. TNS OBOP, Sytuacja materialna polskich rodzin, Warszawa, kwiecień 2000 r., w: www.obop.pl/abin/r/301/062-00.pdf (19.01.2012)

W roku 2003 niemal dwóm piątym Polaków pieniędzy nie starcza na opłacanie podstawowych świadczeń - większości z nich co prawda tylko od czasu do czasu sytuacja taka się przydarza (27\%), ale co dziewiąty z problemami tymi boryka się już od dłuższego czasu (11\%). Połowie z nas (49\%) pieniędzy w domowym budżecie wystarcza akurat na bieżące wydatki. Osoby, które poza zaspokojeniem bieżących potrzeb mogą pozwolić sobie na ekstra wydatki, stanowią w naszym kraju zaledwie 13\%, przy czym w przytłaczającej większości - na zakupy takie rodziny mogą wybrać się raz na jakiś czas, a tylko jedna na sto - każdego miesiąca. Por. TNS OBOP, Sytuacja materialna Polaków-jaka jest? Jaka będzie?, Warszawa, marzec 2003 r., w: www.obop.pl/ abin/r/1386/023-03.pdf (19.01.2012).

Rok 2011 jest jeszcze bardziej okrutny w statystykę, ponieważ aż 64\% Polaków, pieniędzy wystarcza jedynie na bieżące wydatki, a co piąta osoba (20\%) przyznaje, że czasami lub od dłuższego czasu nie jest w stanie opłacić podstawowych świadczeń. Zdaniem jednej trzeciej respondentów (31\%) w ciągu ostatnich 12 miesięcy sytuacja finansowa ich gospodarstw domowych pogorszyła się, z czego $4 \%$ badanych wyraziło tę opinię w sposób zdecydowany. Ponad połowa respondentów (53\%) uważa, że w ostatnim czasie ich sytuacja materialna nie zmieniła się, natomiast 15\% Polaków ocenia, że nastąpiła poprawa (14 \%. - trochę, $1 \%$ - zdecydowanie). Odsetek osób uważających, że ich sytuacja materialna pogorszy się, jest większy o 5 punktów proc. niż przed rokiem. Informacje na podstawie strony http://wiadomosci.wp.pl/title,Fatalna-sytuacjafinansowa-Polakow-jest-coraz-gorzej,wid,14067943, wiadomosc.html (19.01.2012). 
stawiania sytuacji finansowej. Takie zachowanie stanowi obejście konieczności poniesienia kosztów sądowych i jest bezsprzecznie naganne. Pozorowane ubóstwo $\mathrm{w}$ tym przypadku jest niesprawiedliwością w stosunku do Kościoła, ale nadto w stosunku do tych osób, których stan materialny nie jest o wiele lepszy, a pomimo to poczuwają się w obowiązku do uiszczenia stosownych nakładów.

\section{Prawa ubogich $\mathrm{w}$ procesie de nullitatae}

Po analizie dotyczącej pojęcia oraz pozycji osób ubogich, w kolejnym punkcie należy przejść do strony prawnej. Proces kanoniczny o stwierdzenie nieważności małżeństwa jako proces specjalny wpisuje się w ogólną problematykę prawa procesowego. I choć różni się od procesu spornego, Prawodawca w kan. 1691 KPK nakazuje, poza szczegółowymi kanonami (kan. 1671-1688 KPK), aby w pozostałych kwestiach dotyczących postępowania stosować kanony o procesie w ogólności i o zwyczajnym procesie spornym, o ile nie przeciwstawia się temu natura rzeczy i zawsze z zachowaniem norm specjalnych co do spraw o stanie osób i spraw odnoszących się do dobra publicznego. $Z$ tej to racji w omawianym przez nas zagadnieniu odwołamy się przede wszystkim do zasad ogólnych procesu.

Proces de nullitatae zmierza do poznania prawdy o danym małżeństwie. Ma on przede wszystkim przynieść odpowiedź na przedstawione przez stronę powodową twierdzenie, że jej małżeństwo zostało zawarte nieważnie ze względu na występowanie przeszkody, wady zgody lub brak formy kanonicznej. Do zaskarżenia małżeństwa są zdolni sami małżonkowie lub rzecznik sprawiedliwości ${ }^{19}$. W kan. 1476 KPK czytamy, iż każdy może występować przed sądem, niezależnie od tego czy jest ochrzczony czy też nie ${ }^{20}$. Jak podkreśla doktryna podmiotem tego prawa staje się każda osoba. Taka interpretacja wynika z omawianej już wcześniej godności człowieka. Natomiast generalna

\footnotetext{
${ }^{19}$ Kan. 1674 KPK.

${ }^{20}$ Por. kan. 221 §1 KPK: ,Wiernym przysługuje legalne dochodzenie i obrona przysługujących im w Kościele uprawnień na właściwym forum kościelnym według przepisów prawa".
} 
legitymacja ludzi nieochrzczonych jest rezultatem sformułowanego na Soborze Watykańskim II stanowiska o odrzuceniu wszelkiej formy dyskryminacji w stosunkach między ludźmi odnośnie do poszanowania podstawowych praw osoby ludzkiej, między innymi ze względu na religię czy pozycję społeczną ${ }^{21}$. Ze względu na kontradyktoryjny charakter procesu o nieważność małżeństwa oprócz strony powodowej występuje także strona pozwana. Ona także posiada prawa i obowiązki. Jak podkreślał to już papież Jan XXIII osoba ludzka posiada prawo do słusznej obrony swych praw i do obrony skutecznej, równej dla wszystkich i zgodnej z prawdziwymi zasadami sprawiedliwości ${ }^{22}$.

„Nienaruszalne prawo człowieka do zabezpieczenia prawnego wynika z samego prawa Bożego; wiąże się z nim zespół konkretnych uprawnień, chronionych przeciw wszelkim zakusom arbitralności”23. Każdemu człowiekowi, bez jakiejkolwiek dyskryminacji, przysługuje pełnia praw do sądu i do obrony, w tym co dotyka jego osoby. A zatem i ubogim przysługują prawa ustanowione przez Kościół co do występowania jako strona w procesie de nullitatae. Mogą oni po spełnieniu warunku posiadania zdolności procesowej, występować osobiście w procesie na równych prawach i z takimi samymi obowiązkami jak wszyscy pozostali ludzie lub mogą być reprezentowani przez swoich adwokatów lub pełnomocników. Należy nam bowiem stale pamiętać, że każdy człowiek z racji na swoją godność osoby może dochodzić sprawiedliwości, a tym samym chronić swoje prawa i uprawnienia w ramach gwarantowanego mu prawa do $\mathrm{saqdu}^{24}$. Takie traktowanie ubogich staje się gwarancją pojęcia sprawiedliwego sądu.

${ }^{21}$ Sobór WATYKAŃSKI II, Gaudium et spes, n. 29: ,Wszelka jednak dyskryminacja w zakresie fundamentalnych praw osobowych, czy to społeczna, kulturalna, z powodu płci, rasy, koloru skóry, pozycji społecznej, języka czy religii, powinna być przezwyciężona i zlikwidowana jako sprzeczna z zamysłem Bożym”. J. KRUKowski, Kan. 1476, w: Komentarz do Kodeksu Prawa Kanonicznego, pod red. J. Krukowskiego, t. 5, Poznań 2007, s. 99.

${ }^{22}$ Por. JAN XXIII, dz. cyt., n. 27.

${ }^{23}$ Por. PIus XII, dz. cyt. s. 21.

${ }^{24}$ A. BARTCZAK, Prawo do obrony jako gwarancja poszukiwania prawdy obiektywnej o danym małżeństwie w procesie matżeńskim, Prawo i Kościół 3(2011), s. 92. 


\section{Ochrona praw ubogich}

Ze względu na szczególną pozycję osób ubogich, prawodawstwo kościelne chroni grupę ubogich tak, aby ich prawa nie były łamane. W kanonicznym procesie małżeńskim możemy odnaleźć normy, które pozwalają ubogim na ochronę ich podstawowych praw. Wpisują się one bez wątpienia w cel prawodawstwa kościelnego jakim jest salus animarum. Idzie więc o koszta sądowe oraz uzyskanie pomocy prawnej. Jakkolwiek zostaną niżej przedstawione kwestie dotyczące sądownictwa kościelnego ze szczególnym uwzględnieniem sytuacji w Polsce, to należy pamiętać, iż także Trybunał Roty Rzymskiej ma swoje normy dotyczące możliwości zmniejszenia lub zniesienia kosztów sądowych oraz przyznania pomocy prawnej ${ }^{25}$.

\subsection{Koszta sądowe}

Jakkolwiek w Kodeksie Prawa Kanonicznego z 1983 r. nie znajdujemy bezpośrednio wzmianki o kosztach sądowych, poza normami dotyczącymi ich ustanowienia przez Biskupa, to jednak pośrednio jest mowa o ewentualnych zwolnieniach z tego obowiązku. Instrukcja procesowa Dignitas connubii z 2005 r. zawiera przepis stanowiący wprost o obowiązku stron do poniesienia kosztów sądowych ${ }^{26}$. Nie jest to jednak wymóg bezwzględny. Prawodawca w kan. 1649 §1 KPK stanowi, iż Biskup, do którego należy prawo kierowania trybunałem, powinien ustanowić przepisy dotyczące zasądzania i obniżki kosztów sądowych $^{27}$. Ci, którzy nie są w stanie pokryć żadnych wydatków sądowych, mają prawo otrzymać zwolnienie z nich; ci, którzy mogą po-

${ }^{25}$ Por. art. 110-119, Normae Romanae Rotae Tribunal, z 18.04.1994, AAS 86(1994), n. 6 , s. 538-540.

${ }^{26}$ Art. 302 Instrukcji Dignitas connubii. ,Na koszty sądowe składają się niezbędne i celowe wydatki związane $\mathrm{z}$ rozpatrywaniem i rozstrzygnięciem sprawy. Koszty sądowe to wydatki na właściwe funkcjonowanie sądu, honoraria dla adwokatów i biegłych, wynagrodzenia należne świadkom, zapłata za tłumaczenie oraz przepisywanie akt i dokumentów". Por. M. Greszata, Wydatki sadowe oraz bezpłatna pomoc, w: Komentarz do Instrukcji procesowej Dignitas connubii, pod red. T. Rozkruta, Sandomierz 2007, s. 403.

${ }^{27}$ Por. art. 303 Instrukcji Dignitas connubii. 
kryć je w części, mogą uzyskać zmniejszenie kosztów ${ }^{28}$. Tym samym istnieje możliwość zmniejszania lub pominięcia egzekucji obowiązku poniesienia kosztów sądowych.

\subsubsection{Kryteria przyznawania pomocy}

Przepisy wydane przez biskupa powinny zawierać kryteria konieczne do spełnienia dla strony celem obniżenia lub zniesienia kosztów sądowych. Wytyczne przedkłada w tej kwestii Instrukcja Dignitas connubii w art. 306. Idzie więc o: określenie stanu ekonomicznego strony, jej wiarygodność i domniemanie słuszności ${ }^{29}$.

Stan ekonomiczny czyli faktyczna sytuacja finansowa strony w okresie prowadzenia procesu o nieważność małżeństwa. Strona winna w formie pisemnej zwrócić się do trybunału z prośbą o zmniejszenie lub zniesienie całkowite kosztów sądowych ze względu na sytuację finansową. Do prośby powinny być dołączone stosowne dokumenty

\footnotetext{
${ }^{28}$ Por. art. 305 Instrukcji Dignitas connubii.

${ }^{29}$ Chcąc porównać te wymogi do wymogów stawianych przez Prawodawcę z okresu przed 1983 r. należy przytoczyć przepisy Kodeksu z 1917 r. oraz przepisy zawarte w Instrukcji Kongregacji Sakramentów Provida Mater z 15 sierpnia 1936 r. Zgodnie z kan. 1908 CIC oraz art. 232 PM, ,strony powinny być nakłonione do zapłacenia kosztów sądowych, chyba że zostaną zwolnione od tego obowiązku z racji przyznania prawa ubogich". Kto chciałby zwolnić się z obowiązku poniesienia kosztów sądowych winien był przedłożyć przewodniczącemu prośbę, załączając świadectwa wykazujące stan majątkowy. Jednocześnie zainteresowany winien wykazać, że prowadząc spór nie działa niegodziwie i lekkomyślnie (simulque probare debet se, in lite agenda, non futilem neque temerarium causa agere - por. art. $238 \S 1$ PM). W art. 233 PM Prawodawca wskazywał, iż w każdym sądzie powinien znajdować się wykaz taks, ustalony przez synod prowincjonalny lub zjazd biskupów. Jeżeli strona spełniła wszystkie wymogi stawiane przez prawo kolegium winno przyznać bezpłatną opiekę a przewodniczący wyznaczał adwokata (art. 237 §1 PM). To co charakterystyczne dla tamtych uregulowań to fakt, iż taka pomoc mogła być odwołana, ilekroć w toku sprawy wyszło by na jaw z akt sprawy lub nowych dokumentów, iż nie ma podanego stanu ubóstwa. Zob. także: S. Biskupski, Prawo małżeńskie Kościoła Rzymskokatolickiego, t. 2, Olsztyn 1960 s. 463-468; W. Doheny, Canonical Procedure in matrimoniale cases, I-Formal Iudicial Procedure, Milwauke 1948, s. 562.
} 
potwierdzające ten $\operatorname{stan}^{30}$. Można zatem stworzyć otwarty katalog dokumentów i zaświadczeń, które strona mogłaby przedstawić:

- dokument potwierdzający status osoby bezrobotnej z prawem do zasiłku lub bez prawa do zasiłku;

- zaświadczenie o dochodach wystawione przez pracodawcę;

- deklaracja PIT kierowana do Urzędu Skarbowego;

- zaświadczenie o przyznaniu renty chorobowej lub emerytury, z uwzględnieniem wysokości wypłacanego świadczenia;

- zaświadczenie o przyznawanej pomocy z MOPS;

- zaświadczenie o przyznawanej pomocy z diecezjalnej lub parafialnej Caritas;

- zaświadczenie Proboszcza o sytuacji materialnej strony ${ }^{31}$;

- szacunkowe zestawienie wydatków ponoszonych w związku z opłatami;

- koszta ponoszone na skutek leczenia (własnej osoby lub dziecka);

- zaświadczenie o rozdzielności majątkowej (o ile obecnie osoba pozostaje w związku cywilnym z inną osobą).

Wydaje się, że kryteria powinny uwzględniać rzeczywistą sytuację materialną, a więc odwoływać się do zarobków netto. To one bowiem stanowią o faktycznym stanie finansów strony. Z drugiej strony należy wystrzegać się nadmiernej wnikliwości przy ocenie tegoż materiału, tak aby dobro osoby nie zostało naruszone. Idzie więc o poznanie prawdy, aby móc sprawiedliwie określić koszta. W tej trudnej ocenie wikariusz sądowy lub przewodniczący, jeśli uznają to za słuszne, przed podjęciem decyzji, mogą prosić o opinię promotora sprawiedliwości

${ }^{30}$ Już S. Biskupski w swoim komentarzu stwierdzał, iż ani Instrukcja z 1936 r., ani Kodeks z 1917 r. nie przedkładały listy dokumentów, jakie można byłoby przedłożyć starając się o przyznanie praw ubogich. Jednakże jak zaznaczył ,należy przypuszczać, że każdy wiarygodny dowód w formie zaświadczenia urzędów publicznych, a przede wszystkim zaświadczenie duszpasterza, który po sumiennym zbadaniu sprawy, wyda opinię o stanie majątkowym petenta, może stać się dla sądu podstawą do przyznania prawa ubogich". Por. S. BisKuPSKI, dz. cyt., s. 468.

${ }^{31}$ Por. T. Pawluk, Prawo kanoniczne wedtug kodeksu Jana Pawła II, t. 4, Olsztyn 1990, s. 306. 
i obrońcy węzła małżeńskiego, przekazując im prośbę oraz przedłożoną dokumentację ${ }^{32}$.

Ponadto należy zaznaczyć, iż Prawodawca nakazuje stosować domniemanie słuszności (fumus boni iuris). Idzie o rzeczywistą potrzebę udzielenia takiej pomocy. To domniemanie wydaje się jednak możliwe do obalenia. Jak zaznaczono już na początku, także przed trybunałami kościelnymi mamy do czynienia z ludźmi nieuczciwymi. Bo jakie kryterium przyjąć co do osoby, która celowo unika możliwości podjęcia pracy, żyjąc na koszt państwa lub ze środków przeznaczanych przez Unię Europejską? Powstaje pytanie, czy należy traktować inaczej osobę niemogącą znaleźć pracy, a wspomnianą wyżej osobę?

\subsubsection{Decyzja}

Decyzję o kosztach sądowych wydaje sędzia ${ }^{33}$. Ze względu na charakter sprawy mają $\mathrm{w}$ tym przypadku zastosowanie przepisy dotyczące spraw wpadkowych. W kan. 1588 KPK Prawodawca stwierdził, iż sprawę wpadkową przedstawia się wobec sędziego właściwego do rozstrzygnięcia sprawy głównej. Analizując jednak czas w jakim taka decyzja ma być wydana można dostrzec kolizję norm. W Kodeksie z 1983 r. w kan. 1464 czytamy: „Sprawy o zabezpieczenie pokrycia kosztów sądowych lub o przyznanie bezpłatnej pomocy prawnej, które zostały wniesione zaraz na początku, i inne tego rodzaju, winny być rozpatrywane z reguły przed zawiązaniem sporu". W innym miejscu w kan. $1611^{\circ} 4$ KPK Prawodawca określa, iż wyrok powinien ustalić

${ }^{32}$ Por. art. $306^{\circ} 3$ Instrukcji Dignitas connubii.

${ }^{33}$ Por. Sz. Pikus, Niezawisłość sędziego kościelnego, Lublin-Sandomierz 2009, s. 200-202: „Ponieważ ochrona praw przysługujących człowiekowi stanowi ważne zadanie Kościoła, stąd sędzia jest szczególnie zobowiązany respektować godność osoby i gwarantować zachowanie jej praw. (...) Sędzia aplikuje prawo do konkretnej sytuacji, realizuje zadania pastoralne i pozostaje wobec stron duszpasterzem. Zlecona mu przez Prawodawcę cura animarum sprawia, iż zabiega o naturalną sprawiedliwość i respektowanie istotnych praw należnych każdemu człowiekowi”. Por. K. H. SELGE, Der kirchliche Richter als Seelsorger im ordentlichen Ehenichtigkeitsverfahren erster Instanz, w: Adnotationes in iure canonico, Festgabe Franz X. Walter zur Vollendung des 65. Lebensjahres, hrsg. E.Güthoff, K. H. Selge, Fredersdorf 1994, s. 37. 
koszta procesu. Podobne określenie znajdujemy w Instrukcji Dignitas connubii w art. $304 \S 1^{34}$. Gdy idzie jednak o stronę procesową, to zawsze chce ona wiedzieć z jakimi kosztami wiąże się proces de nullitatae. Ma do tego oczywiście prawo, zwłaszcza gdy chodzi o osobę ubogą. Wydaje się zatem, uwzględniając szerszy kontekst, iż koszta te powinny być podane do wiadomości strony lub stron jeszcze przed rozpoczęciem procesu lub na samym jego początku.

Decyzja wydana przez sędziego winna mieć formę dekretu. Sędzia powinien o niej bezzwłocznie poinformować zainteresowaną stronę lub obydwie strony. Decyzja powinna być wydana na podstawie prośby i przedstawionych dokumentów. Jak słusznie zauważa R. Sztychmiler, ustalenie i egzekwowanie kosztów sądowych jest sprawą bardzo delikatną. $Z$ jednej bowiem strony należy liczyć się z realnymi kosztami sądowymi jakie musi ponieść trybunał, a z drugiej strony należy uwzględnić indywidualne możliwości wiernych w danym regionie ${ }^{35}$.

Sędzia swoim dekretem określa zmniejszenie, zniesienie lub rozłożenie na części koszta sądowe. Analogicznie do art. 303 §2 Instrukcji Dignitas connubii, należy stwierdzić, iż sędzia winien mieć na uwadze naturę spraw o nieważność małżeństwa, która wymaga, na ile to możliwe, aby oboje małżonkowie brali udział w procesie dla poznania prawdy obiektywnej ${ }^{36}$. Nadto właśnie Biskup Moderator winien

\footnotetext{
${ }^{34}$ „Kolegium w wyroku ostatecznym ma zadecydować, czy koszty powinny być uregulowane tylko przez powoda, czy także przez drugą stronę, oraz określić proporcjonalny podział zapłaty między dwiema stronami. Określając łączny zwrot kosztów, powinno się jednak uwzględnić okoliczność ubóstwa stron, z zachowaniem przepisów art. 303 (por. kan. 1611, n. 4)".

${ }^{35}$ Por. R. SzTychmiler, Koszty sądowe i bezplatna pomoc, w: Komentarz do Kodeksu Prawa Kanonicznego, pod red. J. Krukowskiego, t. 5, Poznań 2007, s. 307, 309: „Część sądów przeszła już na samofinansowanie. Jednak wtedy koszty sądowe muszą być na ogół znacznie wyższe niż tam, gdzie praca trybunału finansowana jest przez diecezję. Powstaje wtedy problem wyważenia pomiędzy potrzebami procesu, a możliwościami stron".

${ }^{36}$ Por. R. Sobański, Iudex veritatem matrimonio dicit, Ius Matrimoniale 4 (1999), s. 196: „Prawda odkrywana w procesie małżeńskim jest autorytatywną, podjętą w imieniu Kościoła, wiążącą wypowiedzią dotyczącą małżeństwa, opartą na przyporządkowaniu norm kanonicznych i faktów zaszłych w chwili zawierania tegoż konkretnego małżeństwa".
} 
czuwać, aby przez nadmierne koszty, wierni nie byli powstrzymywani w zwracaniu się do sądu, z ciężką szkodą dla dusz, których zbawienie zawsze powinno być w Kościele najwyższym prawem ${ }^{37}$.

\subsubsection{Odwołanie się od decyzji}

Od decyzji sędziego prawo przewiduje skuteczne odwołanie. Od orzeczenia w sprawie kosztów, nie przysługuje oddzielna apelacja, ale strona może się odwołać w ciągu piętnastu dni do tego samego sędziego, który może zmienić ustaloną kwotę ${ }^{38}$. Instrukcja Dignitas connubii wskazuje, że to odwołanie winno być skierowane do kolegium. Różnica tych sformułowań wynika z ogólnie przyjętej w Instrukcji zasady, w myśl której od dekretów przewodniczącego przysługuje rekurs do kolegium. Odwołanie powinno zawierać uzasadnienie przedkładające na tyle mocne argumenty, aby mogło wpłynąć na inną decyzję kolegium.

\subsubsection{Skutki}

Ze względu na wydaną decyzję sędziego co do kosztów procesowych, strona musi wypełnić zobowiązania, które zostały na nią nałożone. Choć w kodeksie nie ma informacji co do skutków takiej decyzji, Prawodawca wypowiedział się na ten temat w Instrukcji Dignitas connubii. Prawodawca przyjął domniemanie, iż podjęta decyzja wywołuje bowiem takie same skutki w kolejnej instancji sądowej. Przedłożył jednak jeden warunek. Przewodniczący kolegium wyższej instancji nie odwoła tej decyzji ${ }^{39}$. W związku z prowadzoną sprawą także na szczeblu II instancji, sędzia trybunału apelacyjnego może określić koszta sądowe. I choć najczęściej są one znacznie niższe niż w trybunale I instancji, to również pokrywają wydatki sądowe. Dlatego pozostawiając autonomię trybunału wyższej instancji Prawodawca określił, iż decyzja sędziego może ulec zmianie, na skutek odwołania jej przez przewodniczącego tegoż trybunału. Muszą jednak zaistnieć okoliczności, któ-

\footnotetext{
${ }^{37}$ Por. art. 308 Instrukcji Dignitas connubii.

${ }^{38}$ Por. kan. 1649 §2 KPK; art. 304 §2 Instrukcji Dignitas connubii.

${ }^{39}$ Por. art. $306^{\circ} 4$ Instrukcji Dignitas connubii.
} 
re znacznie zmieniają sytuację materialną strony. Ponadto zwolnienie z ponoszenia kosztów sądowych może zostać cofnięte przez trybunał apelacyjny, jeśli z wyroku pierwszej instancji wynika brak fumus boni iuris sprawy. Jak zauważa S. Villeggiante odwołanie może nastąpić z urzędu albo na wniosek obrońcy węzła małżeńskiego lub promotora sprawiedliwości ${ }^{40}$.

\subsection{Pomoc prawna}

Proces o nieważność małżeństwa rozpoczyna się od wniesienia skargi ${ }^{41}$. W rzeczywistości, wszczęcie procesu poprzedza podjęcie decyzji o tym przez przynajmniej jedną ze stron. Zgodnie z kan. 1504 KPK skarga winna zawierać kilka punktów, aby spełniała formalne kryteria. Praktyka sądowa pokazuje, że często osoby przychodzące do sądu z myślą wniesienia skargi nie mają rozeznania czy ich sytuacja kwalifikuje się w ogóle do procesu de nullitatae a co za tym często idzie nie mają wiedzy na temat wymogów procesowych. Aby te wątpliwości rozwiać pomocą służą osoby, które uważa się za biegłe w prawie. Wszelką poradą służą adwokaci kościelni oraz pełnomocnicy. Obecnie zauważamy szczególnie rozwój adwokatury kościelnej w Polsce ${ }^{42}$. Zaangażowani są w nią zarówno duchowni, osoby konsekrowane jak też wierni świeccy. Mogą udzielać swoich porad zupełnie prywatnie, w ramach swoich kancelarii albo być zatwierdzonymi przez biskupa ${ }^{43}$ stałymi adwokatami przy konkretnym trybunale. Aby jednak występować w procesie jako adwokat kościelny strony muszą posiadać dokument zatwierdzający wydany przez biskupa do pełnienia tej funkcji ${ }^{44}$.

Osobę ubogą nie stać jest, aby korzystała prywatnie z porady adwokata, albowiem wiąże się to z kosztami finansowymi. Jednakże, aby

\footnotetext{
${ }^{40}$ Por. S. Villeggiante, Il gratuito patrocinio, ,Ephemerides Iuris Canonici 6162(1985-1986), s. 73.

${ }^{41}$ Por. kan. 1502 KPK, kan. 1674 KPK.

${ }^{42}$ Korpus Adwokatów Kościelnych w Polsce. Więcej na ten temat w: A. MizińsKi, Status prawny adwokata w Kościele katolickim, Lublin 2011, s. 538-542.

${ }^{43}$ Por. art. $303 \S 1$ Instrukcji Dignitas connubii.

${ }^{44}$ Por. kan. 1483 KPK.
} 
prawo do sądu, prawo do obrony ${ }^{45}$, wreszcie prawo do swobodnego ustanowienia sobie adwokata nie było łamane, przy każdym trybunale kościelnym powinni być dostępni adwokaci, którzy będą mogli służyć pomocą prawną. Taka opinia znalazła swoje odzwierciedlenie w art. $113 \S 1$ Instrukcji Dignitas connubii: „Przy każdym sądzie powinien być urząd albo osoba, aby każdy mógł swobodnie i szybko uzyskać poradę dotyczącą możliwości i sposobu postępowania zmierzającego, jeśli to okazuje się możliwe, do wprowadzenia swojej sprawy o nieważność małżeństwa”. Dla pożytku wiernych, małżonków broniących swoich praw, biskup diecezjalny powinien stworzyć listę pełnomocników oraz adwokatów dopuszczonych przez niego do reprezentacji stron w sądzie ${ }^{46}$. Ponadto zgodnie z kan. $1649 \S 1^{\circ} 3 \mathrm{KPK}$ to na biskupie ciąży obowiązek wydania stosownych przepisów, które będą dotyczyły przyznawania bezpłatnej pomocy dla stron. W ten sposób zgodnie z prawem strona uboga może prosić o bezpłatną pomoc prawną (gratuitum patrocinium). W Instrukcji procesowej Dignitas connubii w art. 307 znajdujemy normę, która stanowi konieczność udzielenia bezpłatnej pomocy, jeśli taka zostanie stwierdzona przez przewodniczącego. Wtedy też Wikariusz sądowy wskazuje adwokata, który podejmie się takiej pomocy ${ }^{47}$. Każdą taką nominację sędzia powinien podać, w formie dekretu, do wiadomości stron procesowych, rzecznika sprawiedliwości, jeśli w procesie bierze udział oraz obrońcy węzła małżeńskiego ${ }^{48}$. $\mathrm{Na}$ adwokacie spoczywa zobowiązanie do wypełnienia tegoż obowiązku i to z należytą dokładnością. Tylko na skutek ważnej przyczyny rozważonej przez przewodniczącego, adwokat może zostać zwolniony z wykonania swoich obowiązków. Jego praca jest kontrolowana przez przewodniczącego, który może interweniować w sytuacji kiedy adwokat nie wypełnia swojego obowiązku

${ }^{45}$ Por. C. Gullo, A. Gullo, Prassi processuale nelle cause canoniche di nullità del matrimonio. Terza edizione aggiornata con l'Instr. «Dignitas connubii» del 25 gennaio 2005, Città del Vaticano 2009, s. 52-54.

${ }^{46}$ Por. art. $112 \$ 1$ Instrukcji Dignitas connubii.

${ }^{47}$ Zob. P. Moneta, Patrono stabile e deliberazione delle sentenze ecclesiastiche, Il Diritto Ecclesiastico 113(2002), s. 1381.

${ }^{48}$ Por. A. Miziński, dz. cyt, s. 356. 
z należytą dokładnością ${ }^{49}$ a nawet może nałożyć sankcje karne przewidziane przez prawo $^{50}$.

\section{Zakończenie}

Sądownictwo kościelne wpisuje się w sprawowanie władzy rządzenia w Kościele. Jest ona służbą drugiemu człowiekowi. W ten sposób wyraża się idea, że całe prawo kanoniczne nastawione jest na ochronę podmiotowych i przedmiotowych praw osób fizycznych i prawnych ${ }^{51}$. Proces de nullitatae jest procesem szczególnym, nie tylko ze względów formalnych, ale przede wszystkim ze względu na poruszaną materię. Wyrokowanie o nieważności aktu prawnego jakim jest zawarcie małżeństwa, wpływa na sytuację prawną stron. Osoby ubogie mogą także być stronami w procesie, albowiem stan majątkowy nie wpływa kompletnie na zdolność do występowania w sądzie. Ponadto prawodawca ze względu na ich wyjątkową sytuację życiową przedkłada normy, które mają za zadanie gwarantowanie im równości wobec prawa.

Podstawą tego prawa jest bez wątpienia godność człowieka. Prawa osób ubogich są chronione w procesie de nullitatae. Praktyka sądowa wskazuje na przestrzeganie tych przepisów. Warto zauważyć, iż w tym przypadku nie mamy do czynienia z łagodzeniem prawa w stosunku do osób ubogich, ale z ochroną praw przysługujących im ze względu na godność człowieka. To oczywiście pokazuje, iż wbrew opinii promowanej współcześnie, Kościołowi nie zależy na pieniądzach. Koszta sądowe, jakkolwiek ponoszone przez trybunały, nie przesłaniają tego, co jest dla Kościoła najwyższym prawem - zbawienia duszy każdego człowieka.

\section{Protecting the right of the poor in the process of nullity of a marriage}

Human dignity is the basis of the human rights. The law can't discriminate anyone of various factors, especially on his economic situa-

\footnotetext{
${ }^{49}$ Por. art. 307 §3 Instrukcji Dignitas connubii.

${ }^{50}$ Por. S. Villeggiante, dz. cyt., s. 73.

${ }^{51}$ Por. R. SzTYchmiLeR, Ochrona praw człowieka w normach kanonicznego procesu spornego, Olsztyn 2003, s. 35.
} 
tion. The legislatives of the process of nullity of a marriage are including legal norm concern to the poor. They are located in the Code of Canon Law and in the Instruction Dignitas connubii. This regulation determines the possibility of exemption from payment of court fees and gives free legal aid. The article shows the conditions necessary to provide assistance to the poor, the entity issuing the decision and the effects of application of the law. We are dealing with the protection of the rights, but not soften the law. 